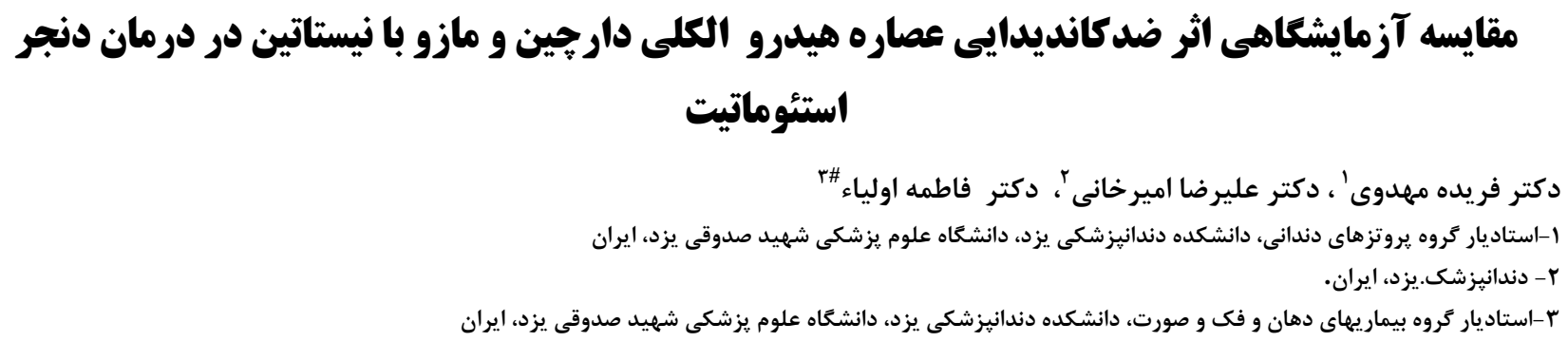

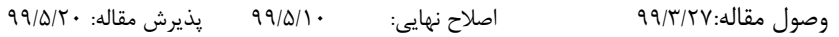

\title{
In vitro comparison of Anti-Candidal Activity of cinnamon and Querques infectoria hydroalcholic extracts with nystatin in treatment of denture stomatitis
}

\author{
Farideh Mahdavi ${ }^{1}$, Alireza Amirkhani ${ }^{2}$, Fatemeh Owlia ${ }^{3 *}$
}

1. Assistant Professor, Prosthodontics Dept, School of Dentistry, Shahid Sadoughi University of Medical Sciences, Yazd, Iran. 2. Private practice. Yazd, Iran.

3.Assistant Professor Oral and maxillofacial Medicine Dept, School of Dentistry, Shahid Sadoughi University of Medical Sciences, Yazd, Iran.

\section{Abstract}

Received: June 2020 ; Accepted: July 2020

Background and Aim: Candida albicans play the main role in the onset, preservation and progression of denture stomatitis. Therefore, the present study was conducted with the aim of comparing the anti candidal effect of cinnamon and Querques infectoria extracts with nystatin for treatment of denture stomatitis.

Materials and methods: In this experimental study, 43 patients with clinical diagnosis of denture stomatitis were selected and maxillary dentures were taken for 24 hours. Dentures randomly were divided into three groups of 14 tests and one denture was considered as a negative control group for immersion in distilled water. From the tissue surface, all dentures were sampled with swab and the samples were transferred to the laboratory after transfer to the culture medium and the colony count (CFU / mm2) was measured. Then, each of the 14 denture groups were immersed in a hydroalcoholic solution of cinnamon (70\%), a hydroalcoholic solution of Querques infectoria $(70 \%)$ and nystatin suspension for 24 hours. After 24 hours, repeat sampling and colony count was measured and then the colony count before and after immersion was compared. Data was analyzed using SPSS17 statistical software, Chi-square, Fisher exact tests and ANOVA.

Results: There was no significant difference between the three groups obtained colony counts of Candida albicans from dentures $(\mathrm{P}$-value $=0.01)$.

Conclusion: Both herbal extracts could be effective on treatment of denture stomatitis. It should be more evaluated in future studies.

Key words: Nystatin, Cinnamon extract, Querques Infectoria Extract, Denture Stomatitis

*Corresponding Author: dr.owlia@mail.com

J Res Dent Sci.2020;17(3): 192-200 
خلاصه:

سابقه و هدف: كانديدا آلبيكنس نقش اصلى را در شروع، حفظ و پيشرفت دنجر استوماتيت بازى مى كنند. لذا مطالعه حاضر با هدف

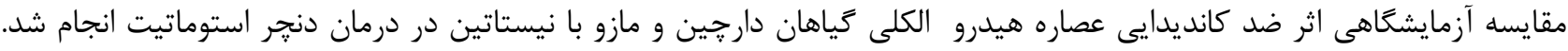

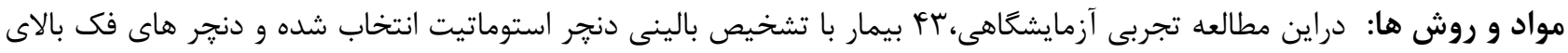

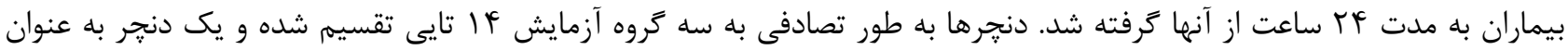

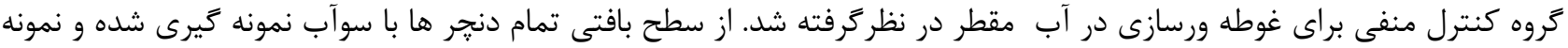

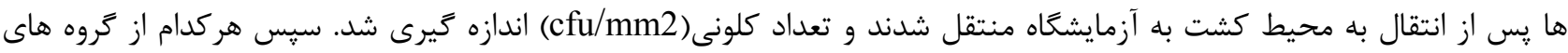

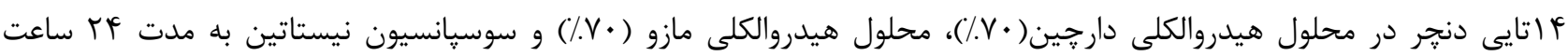

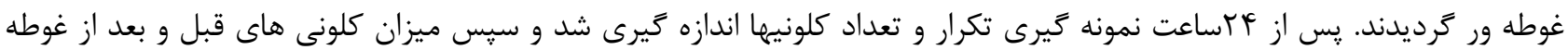

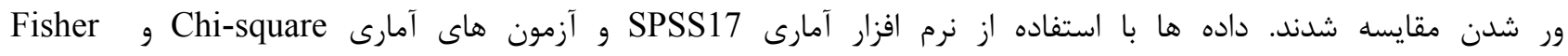
ANOVA,exact يافته ها: تفاوت معنى دارى در سه كروه مورد بررسى در ميزان كلونى به دست آمده كانديداآلبيكنس از دست دند دندان هاى مورد

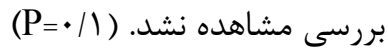

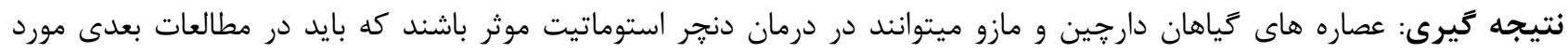
ارزيابى بيشتر قرار كيرد. كليد وازه ها: : نيستاتين، عصاره دارجين، عصاره مازو، دنجر استئوماتيت

در ايران نيز بررسى بر روى بيماران ديابتى نشان داده كه در مقدمه:

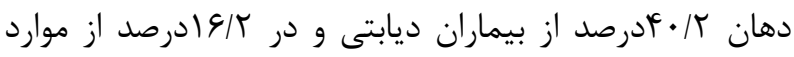

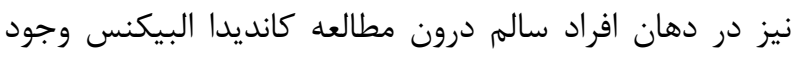

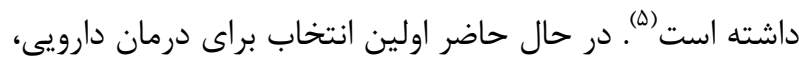
استفاده از تروه دارويى : يلى ان ها ميباشد كه اين كروه شامل

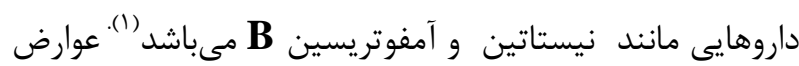
استفاده كردن از داروى نيستاتين شامل اسهال، تهوع، و استفراغ بوده و شكايت اصلى در مورد استفاده از آن مزه بد آن ميباشد.مشكل ديخر اين دارو اين است كه فقط به صورت يودر، پايدار ميباشد و بايد به صورت مداوم محلول آن را درست كرده

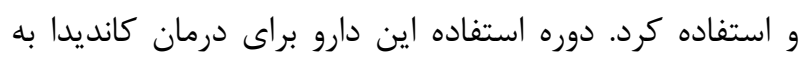

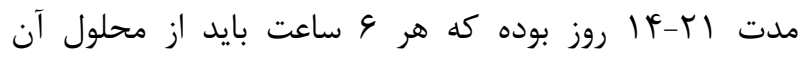

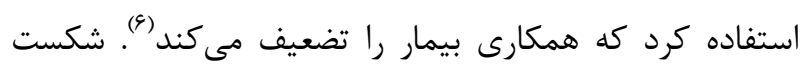
درمان با نيستاتين در بعضى موارد رخ داده كه عوامل زيادى از كانديديازيس دهانى عمدتا از كونه كانديدا آلبيكنس به وجود آمده و شايع ترين عفونت فرصت طلبى است كه دهان را تحت تاثير قرار ميدهد.اين قارج در • † تا • لدرصد افراد سالم جزو فلور طبيعى دهان بوده و در شرايطى مانند تضعيف ايمنى باعث

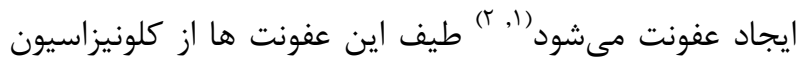
مخاطى تا عفونت هاى مهاجم و كشنده متغير است. از ميان اشكال بالينى مختلف عفونت هاى كانديديايى، كانديديازيس

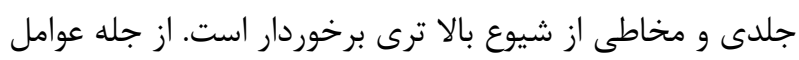

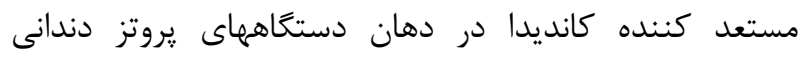
هستند. (r) (") عوارض رشد بيش از حد كانديدا در دهان شامل ناراحتى موضعى، تغيير مزه و ديسفازى ميباشد كه در نتيجه ان باعث سوء تغذيه، كاهش سرعت بهبود و طولانى شدن بسترى در

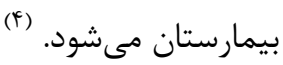

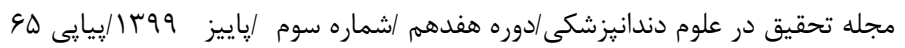


وجود خواص موثر كياهان دارويى براى مقابله با بيمارى هاى دئي عفونى و وجود عوارض مختلف داروهاى شيميايى و همجنين هزينه اقتصادى اندك و روشهاى مختلف مصرف كياهان دارويى وحيى به صورت جوشانده،يودر و استنشاقى توجه بسيارى از مردم را به خود معطوف داشته است (1). اكثر مطالعات مانند مطالعه اربابى-كلاتى و همكاران (9)، حقيقتى و همكاران (19) و مطالعه Lopez و برخى ديكر از محققين نظير Rukayadi و همكاران در كره

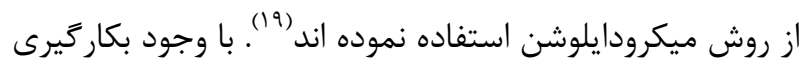
روش هاى مختلف، تمام اين مطالعات خاصيت ضد قارجى عصاره ى دارجين را تاييد نموده اند. لذا اين مطالعه بر آن شد تا با هدف مقايسه آزمايشخاهى اثر ضد قارج عصاره هاى كياهى دارجين و مازو بر قارج كانديدا آلبيكانس با نيستاتين بر روى نمونه هاى گرفته شده از سطح

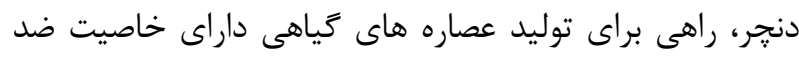

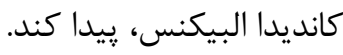

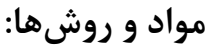

اين مطالعه تجربى- آزمايشگاهى، بر روى دنجر فك بالا

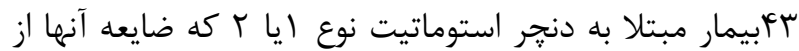
طريق تشخيص بالينى تاييد شده بود از بيماران مراجعه كننده

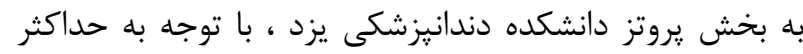

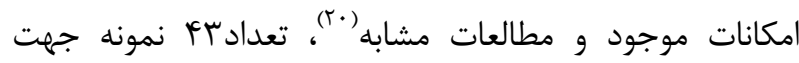
مطالعه انتخاب شده و به صورت تصادفى به سه كروه تقسيم شدند به نحوى كه براى هر كروه ع| نمونه و يك نمونه به منظور كنترل منفى در نظر كرفته شد. جهت رسيدن به دقت و صحت بالاتر نتايج از افشره خالص دارجين و مازو (ساخت شركت آدونيس كل دارو -تهران-ايران) استفاده كرديد كه بنابر ادعاى سازندگان آن بدين صورت تهيه

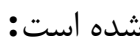

جمله قابليت تميز كنندگى بزاق، و از دسترس خارج كردن دارو

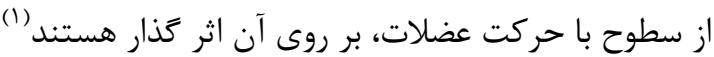
استفاده از گياهان دارويى و طب سنتى از علومى است كه به واسطه تجارب اقوام مختلف صورت گرفته و نسل به نسل انتقال

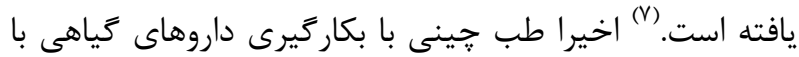

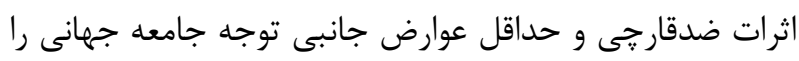

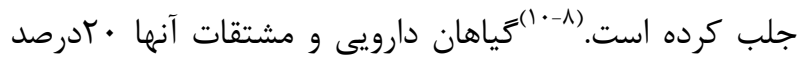
از تجويزات دارويى در كشورهاى ييشرفته و •لدرصد در كشورهاى در حال توسعه را به خود اختصاص مى دهند. (11) از جمله كياهان دارويى ميتوان دارجين را نام برد كه خواص لهاص مفيد مورد نظر آن شامل خاصيت ضد باكتريايى و ضد قارجى

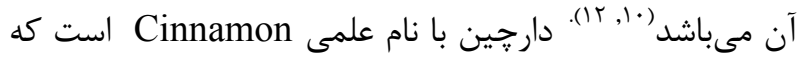
به خانواده برك بوها تعلق دارد و عصاره ساقه كياه و سرشاخه هاى جوان و همجنين روغن بركماى اين كياه كاربرد درمانى

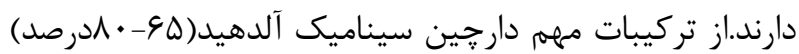

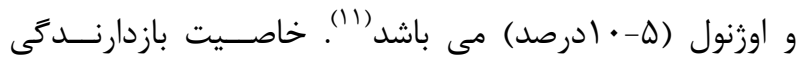

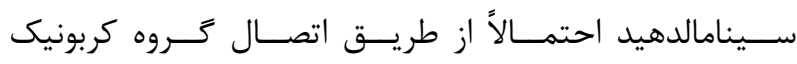

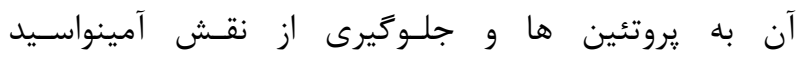
دكربوكسـيلاز مسى باشـد. در مـورد اسـانس هـاى بــا سـاختار آلدهيدى بازدارندكى از رشد ميكرواركانيسم ها به طور عمـده

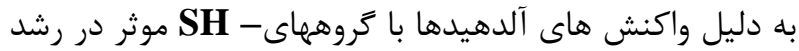
قارج ها مى باشد"ז", (I). اثر ضد باكترى و ضد قارج اسانس دارجين احتمالا به دليل وجود ارتومتوكسى سينامالدئيد (1ه) (1ه) (1ه) كياه ديكر مازو مى باشد كه خواص ضد باكتريايى آن قبلا مورد

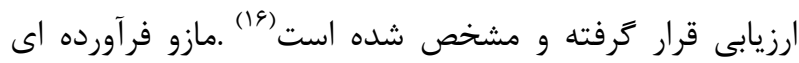
كياهى و كروى شكل است كه بر اثر سوراخ ايجاد شده توسط حشرات بر اثر تخم كذارى بر روى شاخه هاى تازه درخت بلوط به وجود مى آيد. اين فراورده محتوى شيره درخت (صمغ) و

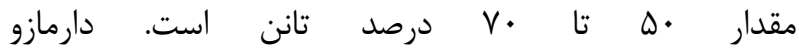
يا يا Aleppo oak يا كه با (Quercus infectoria) نامهاى مازوج يا بلوط حلبى شناخته مى شود. (IV) 
كلونى در ميلى متر مكعب (cfu/mm2) اندازه كيرى شد و به

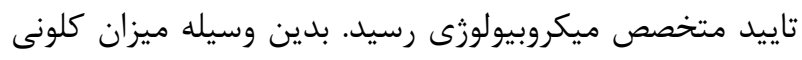

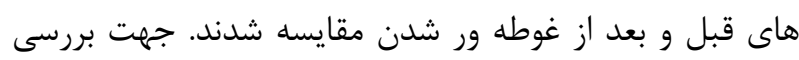

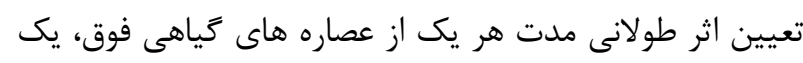

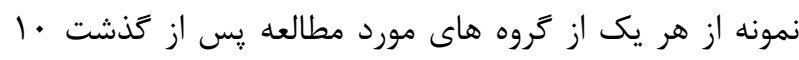

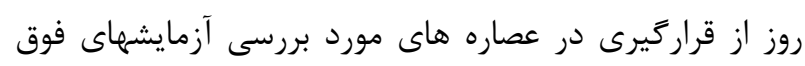
عينا تكرار شد. داده هاى گرد آورى شده با استفاده از نرم افزار كPSS نسخده Vابا استفاده از آزمون هاى آمارى توصيفى و تحليلى با استفاده

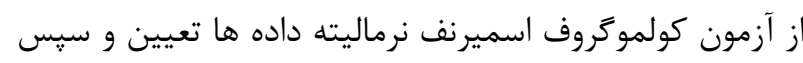

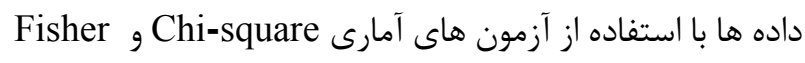
تجزيه و تحليل شدند. لازم به ذكر است كه اين مطالعه در كميته اخلاق در يزوهش دانشكاه علوم يزشكى شهيد بهديد

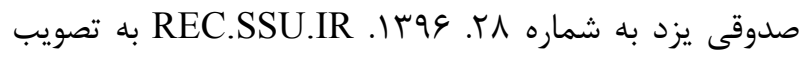
رسيده است.

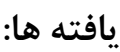
در اين مطالعه از بَ نمونه دست دندان در سه كروها ا تايى و يك نمونه بعنوان كنترل منفى نمونه گيرى شد.بآدست دندان

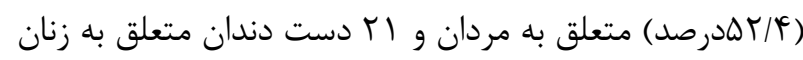

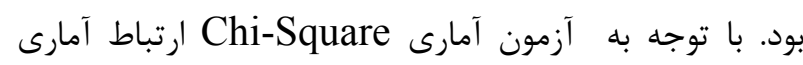
معنى دارى بين سه خروه از نظر توزيع جنسيت مشاهده

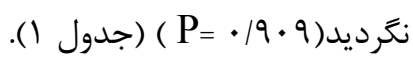

\begin{tabular}{|c|c|c|c|c|c|c|}
\hline & جمع & & زن & & مرد & جنسيت \\
\hline درصد & تعداد & درصد & تعداد & درصد & تعداد & كروه \\
\hline $1 \cdots$ & 14 & $\Delta \cdot$ & v & $\Delta \cdot$ & v & عصاره مازو \\
\hline $1 \ldots$ & 14 & $F r / q$ & 9 & $\Delta \mathrm{V} / \mathrm{l}$ & $\wedge$ & عصاره \\
\hline $1 \ldots$ & 14 & $\Delta$. & $\mathrm{V}$ & $\Delta$. & $\mathrm{v}$ & 'يستاتين \\
\hline $1 \ldots$ & 1 & $1 \cdots$ & 1 & . & . & آب \\
\hline
\end{tabular}

براى استخراج عصاره هيدروالكلى گياهان مورد مطالعه، از روش

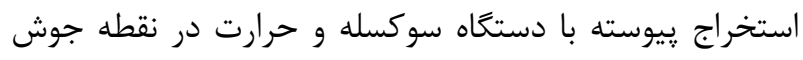
حلال استفاده شد. بدين منظور يودر كياه مورد نظررا به مقدار FVV واتمن ، ريخته و در دستگاه سوكسله يك ليترى قرار داده شد.

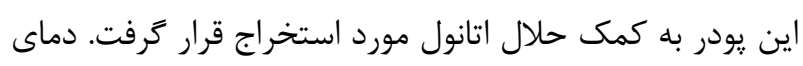

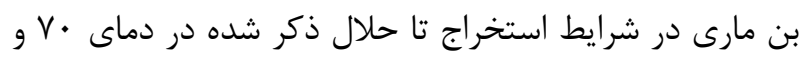

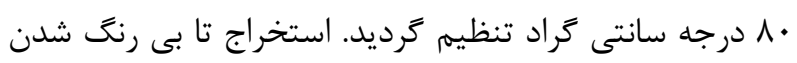

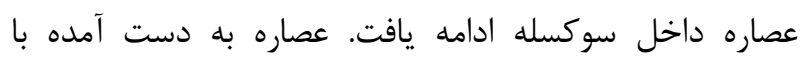

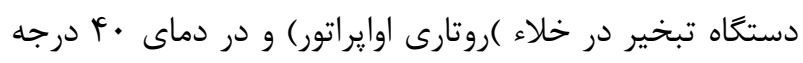
سانتى گراد خشك و در ظروف شيشه اى در بسته تا زمان استفاده در يخجال نكَهدارى شد.

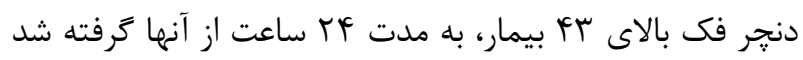
و سيس با توجه به يروتكل درمان ضد قارج ، نيستاتين به آنها

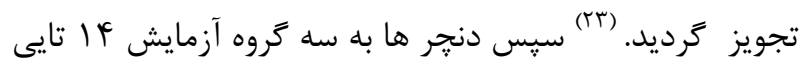

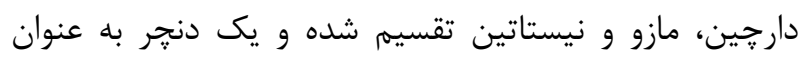

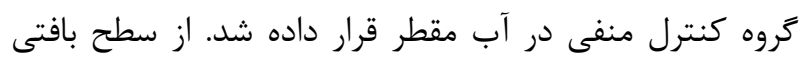

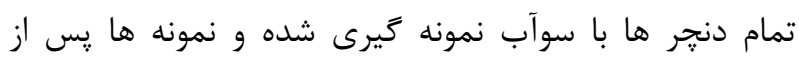

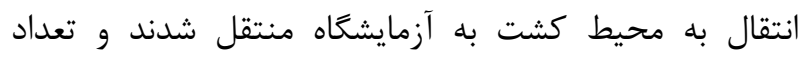

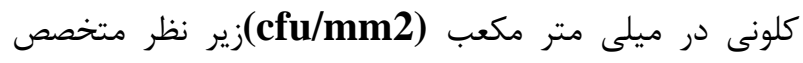

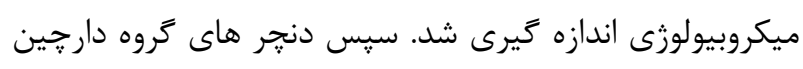

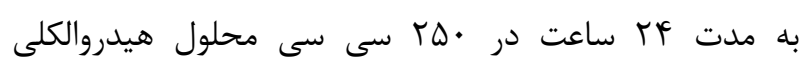

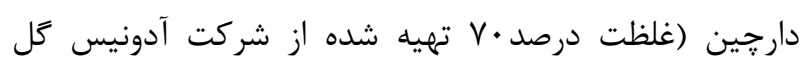

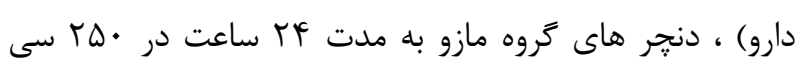

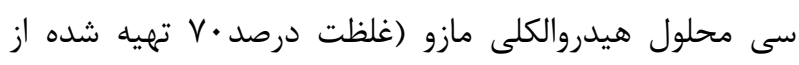

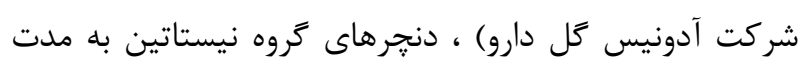

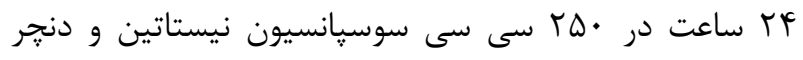

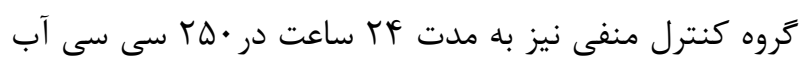

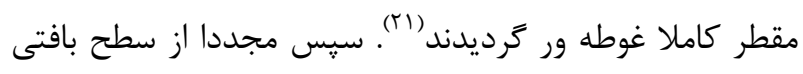
دنجرها با سوآب نمونه گيرى شده و نمونه ها يس از از انتقال به

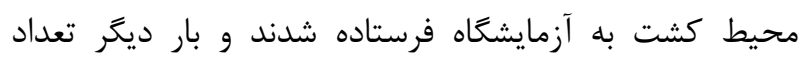

مجله تحقيق در علوم دندانيزشكى/دوره هفدهم/شماره سوم / 
جدول r- توزيع فراوانى وضعيت وجود كلونى بعد از مداخله نسبت

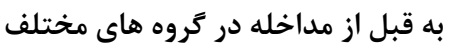

\begin{tabular}{|c|c|c|c|c|}
\hline \multicolumn{2}{|c|}{$>1 \ldots$} & \multicolumn{2}{|c|}{$\leq 1 \cdots \cdots$} & \multirow{2}{*}{ كروه / كلونى } \\
\hline با آلودگى & بدون آلودگى & با آلودكى & بدون آلودگى & \\
\hline$\cdot$ & $r(/.) \cdots)$ & · & $11(/ .1 \cdots)$ & عصاره مازو \\
\hline $1(\%) \cdot)$ & $9(/ .9 \cdot)$ & . & $f(/.) \cdots)$ & ساره دارجين \\
\hline
\end{tabular}

\begin{tabular}{rlll}
\hline & $9(/ .1 \cdot)$ & $\Delta(/)$. & $\cdot$
\end{tabular}

Fisher exact test

$P$-value $=\cdot / 1$

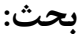

مطالعه ى حاضر بر روى دنجرهايى انجام شد كه براى استفاده

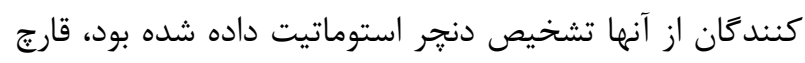

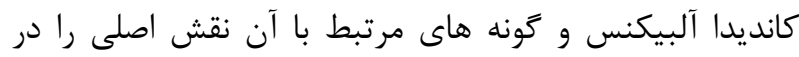
شروع حفظ و ييشرفت دنجر استوماتيت بازى مى كنند (Tr). درمان استوماتيت ناشى از دنجر از جمله رايجترين اقدامات درمانى در حيطه كار بيماريهاى دهان است، امروزه دردرمان اين عفونت ازداروهاى مختلف از قبيل داروهاى تروه آزول(كلوتريمازول،كتوكونازول، فلوكلونازول ) و داروهاى يلى ان (نيستاتين) استفاده مى شود، ولى بررسى هاى مختلف مقاومت كونه هاى مختلف كانديدا را نسبت به داروهاى ضدقارجى نشان

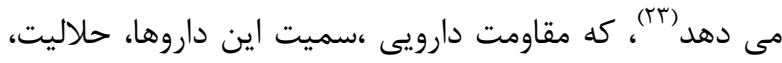

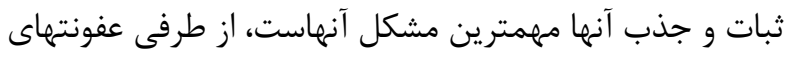
موضعى با نيستاتين درمان ميكردد كه طعم نامطلوبى دارد . بنابراين كاربرد تركيبات با حداقل اثرات جانبى و داشتن طعم مطلوب و قابل قبول در درمان ضايعات ناشى از قارج كانديدا

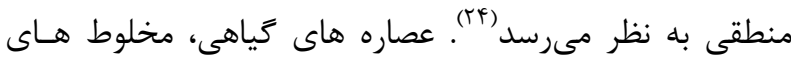
كميلكسى از تركيبـات فرار توليد شده توسط اركانيسم هاى زنسـه بـوده كـه توسـط روشهاى فيزيكى خون عصاره كيرى و تقطير از همه كَياه، يا بخش هايى از كيـاه بدسـت مسى آينـد.

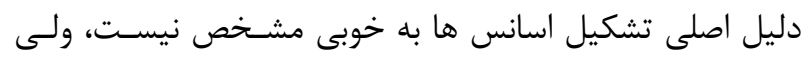

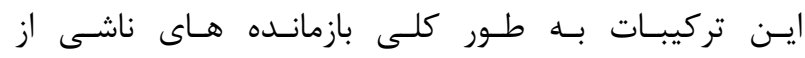
فرايندهاى اصلى متابوليسهم كياهـان بـهـ ويـزّه تحـت تـاثير

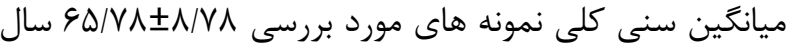

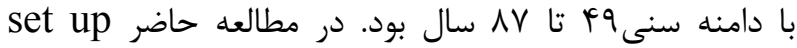
آزمايش با آلوده بودن تمام نمونه ها بخوبى انجام كرفت، به اضافه اين كه نمونه كنترل منفى همم به كلونى آلوده شده بود.

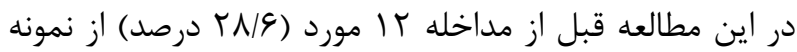

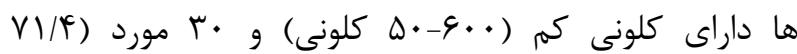
درصد) از نمونه ها داراى كلونى زياد (بالاى ل...... كلونى) بودند بعد از مداخله همه ى نمونه ها بدون كلونى شده بودند،

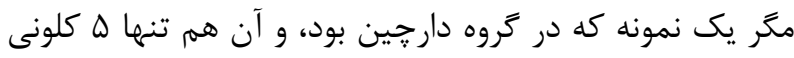
مشاهده كرديد، كه ناجيز بود(جدول ז).

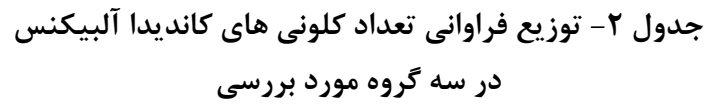

\begin{tabular}{|c|c|c|c|c|}
\hline & بعد از مداخله & & قبل از مداخله & كلر \\
\hline با آلودگى & بدون آلودىى & $\begin{array}{c}1 . . . . \\
\text { تعداد(درصد) }\end{array}$ & $\begin{array}{l}\leq \ldots \\
\text { تعداد(درصد) }\end{array}$ & \\
\hline$\cdot$ & $(1 \cdot \cdot) \mid f$ & $(V \wedge / 9) \backslash 11$ & $(r / / 4) r$ & عصاره مازو \\
\hline$(V / 1) 1$ & $(9 T / 9) 1 r$ & $(V \backslash / \mathcal{F}) 1$. & $(T \wedge / \varepsilon) F$ & عصاره دارجين \\
\hline . & $(1 \cdots) \mid f$ & $9(\xi \varphi / T)$ & $(\Gamma \Delta / v) \Delta$ & نيستاتين \\
\hline- & - & . & $(1 \cdot \cdot) 1$ & آب \\
\hline$\left(T / \Psi^{\mathcal{E}}\right) 1$ & $(9 \vee / 9) \& 1$ & $(\boldsymbol{V} / / \mathcal{F}) r$. & $(T N / 9) \| T$ & جمع \\
\hline
\end{tabular}

جنانجه در جدول ץ ملاحظه مى گردد، سه گروه مورد بررسى قابليت حذف كلونى كانديدآلبيكنس از دست دندان هاى مورد

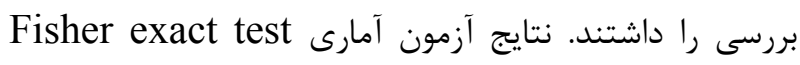

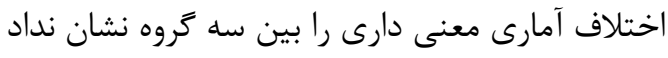
$(\mathrm{P}-$ value $=\cdot / 1)$ 
در مطالعه ى حاضر از غلظت • V درصد عصاره هاى دارجين و مازواستفاده شد. بر اساس نتايج مطالعه Varadarajan و همكاران فعاليت ضد قارجى عصاره هيدروالكلى گياهان دارويى

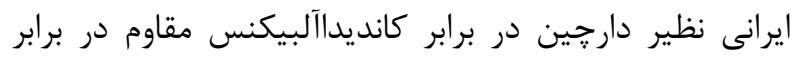
فلوكونازول وابسته به دوز بوده و حداقل دوز براى بروز اين

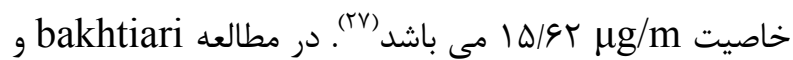
همكاران كه تاثير ضدكانديدايى تركيب مشتق از دارجين را با نيستاتين مقايسه كرده بودند مشخص شد كه كر خه اين تاثير بسزا بود ولى به طور معنى دارى از نيستاتين كمتر بود كه با

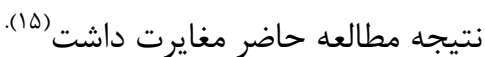
نتايج مطالعه ى كلايى در بررسى حداقل غلظت مهار كنندهى عصارههاى الكلى و آبى دارجين عليه كونهاى كانديدا آلبيكنس در مقايسه با آمفوتريسين B با روش ميكرودايلوشن

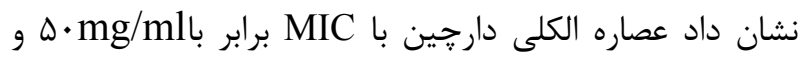

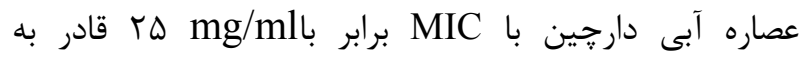
جلوَيرى از رشد قارج كانديدا آلبيكنس داشتند. در مطالعه عطايى و همكاران نيز مشخص شد كه عصاره كياه دارجين در رقت (MIC) ا از رشد قارج كانديدا آلبيكنس جلوكيرى مى

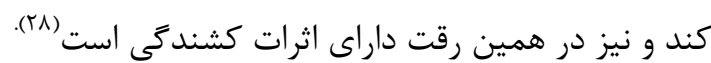
و همكاران در مطالعه اي به اين نتيجه رسيدند كه سينامالدئيد تركيب اصلى ضد قارج روغن تلخيص شده يوست دارجين مى باشد و عناصر ديگر موجود در اين روغن اثر

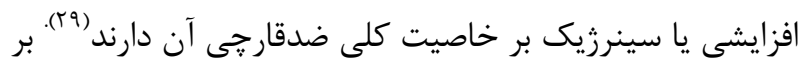

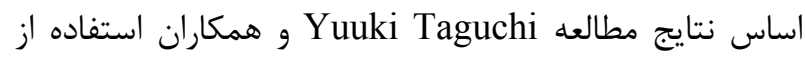
دارجين باعث بهبود علائم و كاهش سلول هاى كانديديايى در حفره دهان موش شده و سينامالدهيد عنصر اصلى بازدارنده

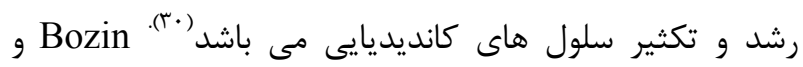

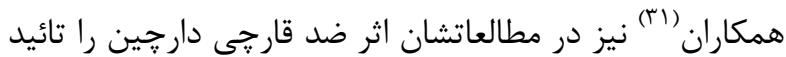
نموده اند .اما تفاوت معنى دارى بين خاصيت ضد قارجى دارجين با نيستاتين گزارش نكردند كه بانتايج مطالعه حاضر لفاص
تنش ها مى باشند كـهـ از نظــــــــيميايى همخـن نبـوده و بـهـ صورتهاى مختلف اغلب با منشا ترينسى مشـاهده مسى

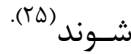

در اين مطالعه اثر ضدقارجى عصاره هاى مازو و دارجين بركانديدا آلبيكنس تاييد شد. به دليل سهولت دسترسى به عصاره اتانولى و نزديكتر بودن عصاره الكلى به كاربرد بالينى، در مطالعه حاضر از عصاره اتانولى استفاده شد. همجنين نتايج مطالعه Bajwa و همكاران نيز نشان داد عصاره الكلى گياهان نسبت به عصاره آبى آنان در سركوب رشد قارج ها بهتر عمل مى كند (1). در اين مطالعه از روش غوطه ورى دست دندان در عصاره ى Vرصد كياهان مازو، دارجين در مقايسه با دهانشويه نيستاتين استفاده شد. با توجه به اين كه استفاده كنندكان از

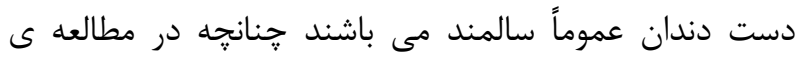

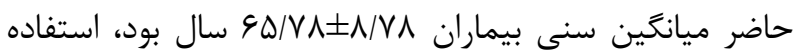
از اين روش عملى تر به نظر مى رسد. البته سنجش فعاليت ضد

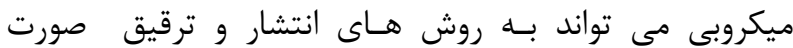

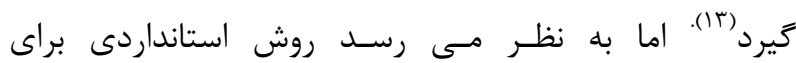
سـنجش فعاليـت ضـد ميكروبى بـر عليـه ميكرواركانسيم هاى مرتبط با دهان ارائه نشده است. با توجه به اين كه نتيجه يك آزمايش مى تواند توسـط فاكتورهاى مختلفى مانـــد روش اسـتخراج اسـانس از زيـاه،

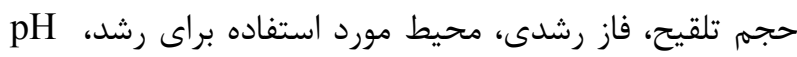

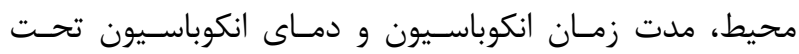

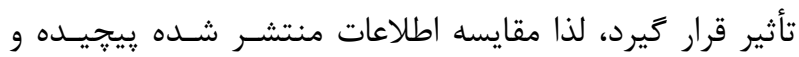
مشكل است. حداقل غلظت ممانعت كننـده (MIC)توسط فيط اكثر محققين به عنوان معيـارى بـراى تعيسين فعاليـت ضـد ميكروبى اسانس ها ذكر شـده اسـت. تعيـين MICدر مقـالات منتشر شده متفاوت است و اين مسئله از موانع ديخر مقايسه

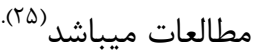

$$
\text { همسو مى باشد. }
$$

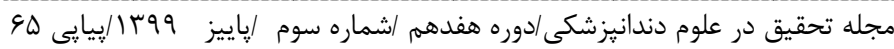




\section{نتيجه گَيرى:}

براساس نتايج تحقيق و با در نظر گرفتن محدوديت ، مى توان گفت هر دو عصاره ى گَياهى دارجين و مازو مانند داروى نيستاتين در حذف كانديدآلبيكنس از يروتز كامل بيماران مبتلا به دنجر استئوماتيت موثر بودند.

\section{تشكر و قدردانى:}

مقاله حاضر برگرفته از يايان نامه دكترى حرفه اي دندانيزشكى مصوب دانشگاه علوم يزشكى يزد ميباشد. بدينوسيله از معاونت يزوهشى دانشعاه علوم يزشكى شهيد صدوقى يزد كه هزينه اين مطالعه را در تقبل نمودند، تشكر و قدردانى ميخردد.

\section{References:}

1-Glick M, Feagans WM. Burket's Oral Medicine. 12th ed. Shelton: PMPH-USA; 2015.

2-Kumar V, Abbas AK, Aster JC. Robbins basic pathology. Philadelphia: Elsevier Health Sciences; 2013.

3-Little JW, Falace D, Miller C, Rhodus NL. Dental Management of the Medically Compromised Patient-Pageburst on VitalSource. 8th ed. Philadelphia: Elsevier Health Sciences; 2012.

4-Akapan A, Morgan R. Oral candidiasis. Postgrad Med J 2002;78(922):455-9.

5-Yar-Ahmadi S, Khosravi A, Larijani B, Baiat M, Mahmoudi M, Baradar-Jalili R. Assessment of the fungal flora and the prevalence of fungal infections in the mouth of diabetics. Iranian Journal of Endocrinology and Metabolism 2002;4(2):105-9.

6-Yagiela JA, Dowd FJ, Johnson B, Mariotti A, Neidle EA. Pharmacology and therapeutics for dentistry. 6th ed. St.Louis: Mosby; 2010.

7-Zare P, Saeedi M, Akbari J, Morteza-Semnani K. A Review on Herbal Oral Care Products. Journal of Mazandaran University of Medical Sciences 2017;26(144):394-410.

8-Wang GS, Deng JH, Ma YH, Shi M, Li B. Mechanisms, clinically curative effects, and antifungal activities of cinnamon oil and pogostemon oil complex against three species of Candida. J Tradit Chin Med 2012;32(1):19-24.

9-Arbabi-klati F, SHerzaee M, Poorzamani M, Dabiri S. Inhibitory Effects of Plant Extracts Containing Thyme, Clore and Cinnamon Compared to Nystatin On Candida Albicans. (Invitro). J Res Dent Sci 2012;8(4):175-9.
مازو از زمانهاى قديم به عنوان گياه دارويى شناخته شده مورد استفاده بوده است. ززارش شده عصاره متانولى زياه مازو حداكثر عملكرد را عليه باكتريهاى، Streptococcus Streptococcus mutans, Staphylococcus ،salivarius Lactobacillus acidophilusgaureus همين طورLeela و همكارش اثرات ضد باكتريايى متانولى، اتانولى و آبى مازو را برضد باكتريهاى گرم مثبت و منفى با روش ديسك نشان داد(זr). اثرات ضد قارجى گياه مازو كمتر مورد بررسى قرار گرفته و بيشتر اثرات ضدباكتريايى اين گياه بررسى شده است.بر اساس نتايج مطالعه حقيقتى و همكاران عصاره مازو با غلظت // • داراى اثرات قابل توجه ضد باكتريايى و ضد قارجى مى باشد (1). در مطالعه نورى و همكاران عصاره كياه مازو اثر ضد قارجى خوبى از خود نشان دادكه با يافته مطالعه ى حاضر در زمينه اثرات ضد قارجى مازو هماهنگى

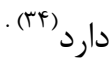

در مطالعه حاضر اثر ضد كانديدايى عصاره گياهان دارجين و مازو بر كانديدا آلبيكنس بر اساس شمارش كلنى انجام شد، جرا كه مشخص شده است كه اثر بازدارندگى برخسى از تركيبات گياهى با قابليت تشكيل كلنى ارتباط دارد. تفاوت در حساسيت مخمرهاى مختلف به عصاره ها علاوه بر نوع مخمر و تركيب شيميايى عصاره به مرحلـه رشد سلول وابسته است. به گونه اى كه سلولها در مرحله تقسيم سلولى نسبت به اثر ضدميكروبى عصاره بسيار حساستر هستند (ها). از نقاط قوت اين مطالعه استفاده از روش غوطه ورسازى بود كه به جاى روش آزمايشگاهى ديسك كه در اكثر مطالعات قبلى مورد استفاده قرار گرفته بود انتخاب شد تا بدين زونه به مصرف دهانشويه توسط بيمار نزديك گردد. در مطالعه حاضر با توجه به عدم در دسترس بودن نتايج اثبات شده در مورد عصاره مازو در مطالعات انسانى ناگزير طراحى مطالعه به صورت آزمايشخاهى انجام شد لذا ييشنهاد ميشود در مطالعات آتى از اين تركيبات به صورت دهانشويه با غلظتهاى مشابه و كمتر جهت درمان دنجر استوماتيت طراحى شود. 
10-Fani MM, Kohanteb J. Inhibitory activity of Cinnamomum Zeylanicum and Eucalyptus Globulus Oils on Streptococcus Mutans, Staphylococcus Aureus, and candida species isolated from patients with oral infections. Journal of Dentistry, Shiraz University of Medical Sciences 2011;11:14-22.

11-Shahinfar J, Zeraati H, Zahrab M, Tashakori M. The Efficiency of Cinnamomum Versus Diazepam on Pre-operative Anxiety in Orthopedic Surgery. Journal of Islamic and Iranian Traditional Medicine 2016;7(2):207-14.

12-Jamshidi M, Barzegar M, Sahari M. Effect of gamma irradiation on the antioxidant and antimicrobial activities of cinnnamon powder. Iranian Journal of Nutrition Sciences \& Food Technology 2013;7(4):73-82.

13-Shahnia M, Khaksar R. Antimicrobial effects and determination of minimum inhibitory concentration (MIC) methods of essential oils against pathogenic bacteria. Iranian Journal of Nutrition Sciences \& Food Technology 2013;7(5):949-55.

14-Elgammal E, El Gendy AEN, Elgamal AE-B. Mechanism of action and bioactivities of $<\mathrm{i}>$ Cinnamomum zeylanicum $</ \mathrm{i}>$ essential oil against some pathogenic microbes. Egyptian Pharmaceutical Journal 2020;19(2):162-71.

15-Bakhtiari S, Jafari S, Taheri JB, Kashi TSJ, Namazi Z, Iman $M$, et al. The Effects of Cinnamaldehyde (Cinnamon Derivatives) and Nystatin on Candida Albicans and Candida Glabrata. Open Access Maced J Med Sci 2019;7(7):1067-70.

16-Haghighati F, Jafari S, Beyt-Elahi JM. Comparison of antimicrobial effects of ten Herbal extracts with chlorhexidine on three different oral pathogens; an in vitro study. Mirror of Heritage 2003;6(3):71-6.

17-Michel-Crosato E, Gonzales PS, Hebling E, de Oliveira RN, Biazevic MGH. Translation and validation of the Brazilian version of the Dentist Satisfaction Survey. Clinical and Laboratorial Research in Dentistry 2014;20(4):234-43.

18-Lopez P, Sanchez C, Batlle R, Nerin C. Solid- and vapor-phase antimicrobial activities of six essential oils: susceptibility of selected foodborne bacterial and fungal strains. J Agric Food Chem 2005;53(17):6939-46.

19-Glick M, Feagans WM. Burket's Oral Medicine. 12th ed. Shelton: PMPH-USA; 2015.

20-Kumar V, Abbas AK, Aster JC. Robbins basic pathology. Philadelphia: Elsevier Health Sciences; 2013.

21-Little JW, Falace D, Miller C, Rhodus NL. Dental Management of the Medically Compromised PatientPageburst on VitalSource. 8th ed. Philadelphia: Elsevier Health Sciences; 2012.
22-Akapan A, Morgan R. Oral candidiasis. Postgrad Med J 2002;78(922):455-9.

23-Yar-Ahmadi S, Khosravi A, Larijani B, Baiat M, Mahmoudi M, Baradar-Jalili R. Assessment of the fungal flora and the prevalence of fungal infections in the mouth of diabetics. Iranian Journal of Endocrinology and Metabolism 2002;4(2):105-9.

24-Yagiela JA, Dowd FJ, Johnson B, Mariotti A, Neidle EA. Pharmacology and therapeutics for dentistry. 6th ed. St.Louis: Mosby; 2010.

25-Zare P, Saeedi M, Akbari J, Morteza-Semnani K. A Review on Herbal Oral Care Products. Journal of Mazandaran University of Medical Sciences 2017;26(144):394-410.

26-Wang GS, Deng JH, Ma YH, Shi M, Li B. Mechanisms, clinically curative effects, and antifungal activities of cinnamon oil and pogostemon oil complex against three species of Candida. J Tradit Chin Med 2012;32(1):19-24.

27-Arbabi-klati F, SHerzaee M, Poorzamani M, Dabiri S. Inhibitory Effects of Plant Extracts Containing Thyme, Clore and Cinnamon Compared to Nystatin On Candida Albicans. (Invitro). J Res Dent Sci 2012;8(4):175-79.

28-Fani MM, Kohanteb J. Inhibitory activity of Cinnamomum Zeylanicum and Eucalyptus Globulus Oils on Streptococcus Mutans, Staphylococcus Aureus, and candida species isolated from patients with oral infections. Journal of Dentistry, Shiraz University of Medical Sciences 2011;11:14-22.

29-Shahinfar J, Zeraati H, Zahrab M, Tashakori M. The Efficiency of Cinnamomum Versus Diazepam on Preoperative Anxiety in Orthopedic Surgery. Journal of Islamic and Iranian Traditional Medicine 2016;7(2):207-14.

30-Taguchi Y, Takizawa T, Ishibashi H, Sagawa T, Arai $\mathrm{R}$, Inoue $\mathrm{S}$, et al. Therapeutic effects on murine oral candidiasis by oral administration of cassia (Cinnamomum cassia) preparation. Nihon Ishinkin Gakkai Zasshi 2010;51(1):13-21.

31-Bozin B, Mimica-Dukic N, Samojlik I, Jovin E. Antimicrobial and antioxidant properties of rosemary and sage (Rosmarinus officinalis L. and Salvia officinalis L.,Lamiaceae) essential oils. J Agric Food Chem 2007;55(19):7879-85.

32-Basri DF, Fan SH. The potential of aqueous and acetone extracts of galls of Quercus infectoria as antibacterial agents. Indian J Pharmacol 2005;37(1):269.

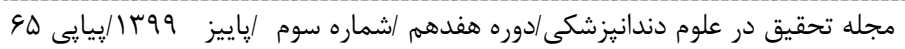


33-Leela T, Satirapipathkul C. Studies on the antibacterial activity of Quercus infectoria galls. In: International Conference on Bioscience, Biochemistry and Bioinformatics, Singapore; 2011; 2011.

34-Nouri F, Raoofi A, Dadfar S. Antifungal Activity of Lavandula Angustifolia and Quergues Infectoria Extracts in Comparison with Nystatin on Candida Albicans. J Hamadan Univ Med Sci 2016;23 (2):172-8,

35-Raval BP, Shah TG, Suthar MP, Ganure AL. Screening of Nigella Sativa Seeds for antifungal activity. Ann Biolog Res 2010;1(1):164-71 